\title{
Implementasi Nilai Pancasila Sebagai Pendidikan Moral Bagi Anak Bangsa
}

\author{
Lisna Amelia ${ }^{1}$, Dinie Anggraeni Dewi ${ }^{2}$
}

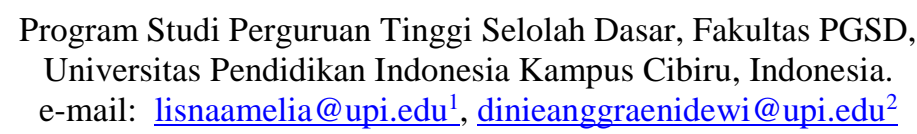

\begin{abstract}
Abstrak
Tulisan ini bertujuan untuk mengetahui dan menganalisis lebih dalam dengan mencari relevansi dan teori-teori mengenai implementasi nilai pancasila sebagai pendidikan moral bagi anak bangsa. Seiring dengan perkembangan zaman dan kemajuan teknologi, perilaku moral anak bangsa merupakan salah satu hal yang sangat penting yang perlu ditingkatkan dan perlu untuk selalu mendapat perhatian. Dapat dilihat pada masa perkambangan teknologi yang semakin pesat dan banyaknya sebuah perubahan, krisisnya perkembangan moral anak bangsa semakin lama semakin buruk dan banyaknya kasus penyimpangan moral pada anak bangsa. Agar anak bangsa memiliki kepribadian yang mandiri, menjadi warga negara yang demokratis, bertanggung jawab, mampu mengenal nilainilai moral, memiliki komitmen moral terhadap perilaku yang konsisten dengan nilai-nilai moral serta memahami nilai-nilai Pancasila dalam kehidupan sehari- hari. Penelitian ini menggunakan metode kualitatif atau pendekatan secara deskriptif dimana teori ataupun dasar pembahasannya diperoleh dari hasil studi kepustakaan dari berbagai sumber seperti jurnal, artikel, dan buku. Pendidikan moral mencakup pada pendekatan dan metode yang mengajarkan pada anak bangsa tentang pengetahuan, bersikap, keteramilan, keyakinan, dan tingkah laku moral yang baik, adil, benar, jujur, peduli terhadap sesama dan lain-lain.
\end{abstract}

Kata kunci: Pancasila, Pendidikan moral, Implementasi nilai-nilai Pancasila

\section{Implementation Of Pancasila Value As Moral Education For Nation Children}

\begin{abstract}
This paper aims to find out and analyze more deeply by looking for relevance and theories regarding the implementation of Pancasila values as moral education for the nation's children. Along with the times and advances in technology, the moral behavior of the nation's children is one very important thing that needs to be improved and needs to always receive attention. It can be seen that during the time of rapid technological development and the number of changes, the crisis in the moral development of the nation's children was getting worse and there were many cases of moral deviation among the nation's children. So that the nation's children have an independent personality, become democratic, responsible citizens, are able to recognize moral values, have a moral commitment to behavior that is consistent with moral values and understand the values of Pancasila in everyday life. This study uses a qualitative method or a descriptive approach where the theory or basis for discussion is obtained from the results of literature studies from various sources such as journals, articles and books. Moral education includes approaches and methods that teach the nation's children about knowledge, attitudes, pregnancy, beliefs, and moral behavior that are good, fair, correct, honest, caring for others and other Keywords: Pancasila, Moral education, Pancasila value implementation
\end{abstract}

\section{PENDAHULUAN}

Pendidikan merupakan usaha sadar manusia dalam membina kepribadiannya sesuai dengan nilai-nilai yang ada pada masyarakat. Nilai-nilai yang ada pada masyarakat harus dibarengi dengan adanya suatu proses pendidikan. Hasil yang diperoleh dari pendidikan tidak hanya sebuah wawasan, ilmu, dan pengetahuan yang luas, tetapi dapat juga memperoleh akhlak yang baik, memiliki pengalaman yang berguna dan bermanfaat bagi masyarakat dan sebagainya. Memperoleh ilmu yang dapat diamalkan kepada banyak orang tentunya hal yang sangat positif dan memiliki nilai yang baik. Tetapi ilmu yang diamalkan kepada banyak orang tentunya harus dibarengi dengan sebuah adab, adapun tingkatan yang lebih tinggi dari ilmu yaitu adab. Karena sebanyak apapun ilmu tanpa disertai dengan adab yang baik akan bisa menjadikan manusia pun berprilaku yang tidak sesuai nilai moral. Memiliki ilmu yang luas tetapi harus disertai dengan adab yang baik juga.

Menurut Ki Hajar Dewantara menyatakan bahwa pendidikan umumnya berarti daya upaya untuk memajukan tumbuhnya budi pekerti (kekuatan batin, karakter), pikiran (intelek), dan tubuh anak. Selain itu 
menurutnya juga, bahwa Pendidikan merupakan upaya untuk memajukan budi pekerti, pikiran serta jasmani anak, agar mampu memajukan kesempurnaan hidup dan menghidupkan anak yang selaras dengan alam dan masyarakat. Pada hakikatnya Pendidikan ialah usaha sadar manusia untuk melestarikan hidupnya [1].

Pendidikan moral merupakan proses pembelajaran dimana peserta didik mampu dalam memahami diri sendiri maupun yang ada disekitarnya. Pendidikan moral sangat perlu untuk dikembangkan bagi anak bangsa, apabila pendidikan moral dijungjung tinggi oleh anak bangsa maka bangsa ini akan lebih baik, karena anak bangsa akan menjadi generasi penerus pada masa yang akan datang. Maka pendidikan moral perlu untuk diterapkan, agar anak bangsa memiliki kepribadian yang mandiri, menjadi warga negara yang demokratis, bertanggung jawab, mampu mengenal nilai-nilai moral serta memiliki komitmen moral terhadap perilaku yang konsisten dengan nilainilai moral [2]. Pendidika moral bagi anak bangsa bertujuan agar anak bangsa mampu meningkatkan kapasitas pola berpikir secara moral serta dapat membantu anak bangsa untuk mengenal apa yang menjadi dasar untuk menerima suatu nilai.

Seiring dengan perkembangan zaman dan kemajuan teknologi, perilaku moral anak bangsa merupakan salah satu hal yang sangat penting yang perlu ditingkatkan dan perlu untuk selalu mendapat perhatian. Dapat dilihat pada masa perkambangan teknologi yang semakin pesat dan banyaknya sebuah perubahan, krisisnya perkembangan moral anak bangsa semakin lama semakin buruk dan banyaknya kasus penyimpangan moral pada anak bangsa.

Pendidikan moral yang diberikan baik di sekolah, keluarga, maupun lingkungan masyarakat perlu disertai dengan penerapan nilai-nilai pancasila sebagai upaya pencerdasan moral bagi anak bangsa. Agar anak bangsa memiliki rasa toleransi, memiliki keyakinan, kekeluargaan, jujur, bersikap adil, benar, peduli terhadap sesama dan sebagainya. Penerapan nilai-nilai pancasila sebagai Pendidikan moral bertujuan untuk menanamkan sikap dan perilaku dalam kehidupan sehari-hari.

\section{METODE PENELITIAN}

Penelitian ini menggunakan metode penelitian secara kualitatif atau pendekatan deskriptif. Istilah penelitian kualitatif menurut Kirk dan Miller (1986) pada mulanya bersumber pada pengamatan kualitatif yang dipertentangkan dengan pengamatan kuantitatif bahwa metodologi kualitatif adalah tradisi tertentu dalam ilmu pengetahuan sosial yang secara fundamental bergantung pada pengamatan pada manusia dan berhubungan dengan orang-orang tersebut dalam bahasanya dan dalam peristilahannya [3]. Pada penelitian ini sumber data yang di peroleh adalah hasil dari studi kepustakaan dari bagai sumber referensi seperti sumber data jurnal dan artikel. Sebagai data yang diperoleh dari sumber tersebut untuk mendukung penelitian ini. Dari berbagai hasil sumber referensi yang ada peneliti mengkaji dan menganalisis lebih dalam. Langkah-langkah analisis kualitatif deskriptif adalah sebagai berikut:

1. Pengumpulan data

Pengumpulan data dapat dilakukan dengan mencari, mencatat dan mengumpulkan semua data secara objektif dan apa adanya sesuai dengan hasil observasi yaitu pencatatan data yang diperlukan terhadap berbagai jenis data dan berbagai bentuk data yang ada di lapangan yang diturunkan peneliti serta melakukan pencatatan di lapangan.

2. Reduksi data

Dalam penelitian ini peneliti melakukan penumpulan data dengan memilih dan menyelseksi data dari hasil obseravasi dan dokumentasi. Kemudian dari hasil observasi tersebut dikaji dan diolah menjadi sebuah hasil.

\section{KAJIAN PUSTAKA}

Pancasila merupakan ideologi dasar negara Indonesia dan untuk menjadi warga negara yang baik (good citizen) di Indonesia harus sesuai dengan Pancasila dan Undang-Undang Dasar 1945. Hal inilah yang mendasari betapa pentingnya Pancasila sebagai acuan ataupun pedoman tentang bagaimana berperilaku menjadi warga negara yang baik (good citizen) di Indonesia. Nilai-nilai yang terkandung dalam Pancasila akan mengajarkan cara berpikir dan bertindak yang sesuai dengan ideologi negara [4].

Nilai-nilai Pancasila juga merupakan suatu pandangan hidup bangsa Indonesia. Pancasila juga merupakan nilai-nilai yang sesuai dengan hati nurani bangsa Indonesia, karena bersumber pada kepribadian bangsa. Nilainilai Pancasila ini menjadi landasan dasar, serta motivasi atas segala perbuatan baik dalam kehidupan sehari-hari dan dalam kenegaraan. Dalam kehidupan kenegaraan, perwujudan nilai Pancasila harus tampak dalam suatu peraturan perundangan yang berlaku di Indonesia. Karena dengan tampaknya Pancasila dalam suatu peraturan dapat menuntun seluruh masyarakat dalam atau luar kampus untuk bersikap sesuai dengan peraturan perundangan yang disesuaikan dengan Pancasila [5]. Pancasila berisi serangkaian nilai berupa ketuhanan atau keyakinan, kemausiaan, kerakyatan, persatuan, dan keadilan. Nilai-nilai tersebut merupakan satu kesatuan yang utuh untuk mengacu pada tujuan yang sama. 
Pada aspek tujuan pendidikan nasional yang terdapat dalam pasal 3 Undang-Undang Nomor 20 Tahun 2003 Tentang Sistem Pendidikan Nasional untuk berkembangnya potensi peserta didik agar menjadi manusia yang beriman dan bertaqwa kepada Tuhan Yang Maha Esa, berakhlak mulia, sehat, berilmu, cakap, kreatif, mandiri dan menjadi warga negara yang demokratis serta bertanggung jawab. Mencerdaskan kehidupan bangsa merupakan lingkup filosofis serta yuridis arti Pendidikan yang melandasi pendidikan di Indonesia [1].

Nilai-nilai yang terkandung dalam Pancasila merupakan sebuah acuan bagi anak bangsa untuk meningkatkan kesadaran bahwa Pendidikan moral sangatlah penting dan harus ditanamkan dalam kehidupan sehari-hari serta dapat berkurangnya kasus penyimpangan moral. Penerapan nilai Pancasila sangat diperlukan karena setiap orang perlu untuk memahai akan rasa saling toleransi, bersikap adil, berkemanusiaan, gotong-royong, kekeluargaan dan sebagainya agar warga negara dapat menempatkan kesatuan, persatuan dan kepentingan negara dari kepentingan masing-masing.

\section{HASIL DAN PEMBAHASAN}

\section{A. Pendidikan Moral Anak Bangsa}

Pendidikan moral adalah upaya dalam membentuk tingkah laku yang baik, yang sesuai dengan harapn masyarakat serta dilakukan secara sadar. Dalam (Sudarminta, 004:108) menyatakan bahwa pendidikan moral pada umumnya, baik di dalam keluarga maupun di sekolah, sebagai bagian pendidikan nilai, adalah upaya untuk membantu anak-anak mengenal, menyadari pentingnya, dan menghayati nilai-nilai moral yang seharusnya dijadikan panduan bagi sikap dan tingkah lakunya sebagai manusia, baik secara perorangan maupun bersama-sama dalam suatu masyarakat [1].

Sejalan dengan perkembangan zaman dan perkembangan teknologi yang semakin pesat, banyak sekali perubahan-perubahan yang ada pada anak bangsa maupun masyarakat sekitar. Lunturnya Pendidikan moral yang ada pada anak bangsa karena kurangnya sebuah perhatian dan kurang diaplikasikan atau diperaktikan di dalam kehidupan sehari-hari. Hal tersebut dapat meyakibatkan kurangnya dalam berprilaku dan bersikap baik, kurang bertanggung jawab, kurangnya taat terhadap aturan, dan sebagainya. Selain itu perubahan yang dialami anak bangsa karena adanya beberapa faktor, yaitu faktor internal dan eksternal. Faktor internal meliputi krisis identitas dan kontrol diri yang lemah; faktor eksternal meliputi kurangya perhatian atau kasih sayang orang tua, minimya pemahaman tentang keagamaan, pengaruh dari lingkungan sekitar, dan tempat Pendidikan. Perlunya penanaman ataupun penerapan Pendidikan moral bagi anak bangsa dari sejak dini agar setiap anak dapat memahami suatu keadaan dan dapat menyejahterakan kehidupannya baik untuk hidup yang sedang dijalankannya maupun kesejahteraan bagi masa yang akan datang.

Begitu besar harapan bangsa pada mereka, apabila pendidikan moralnya masih krisis maka hal tersebut akan mengancam masa depan mereka baik masa depan bangsa ini. Dapat diketahi dari sebuah berita yang pernah viral tersebarnya video prank anak muda menimpa salah satu youtuber yang mana seharusnya memberikan contoh yang baik kepada masyarakat justru memperlihatkan perilaku yang tidak beretika dengan berpura-pura memberikan bingkisan berisi sampah dan batu yang ia bagikan ke salah satunya ke transgender di tengah pandemik, kemudian ia membuat video seolah-olah permintaan maaf yang ternyata hanya prank. Tidak lama setelah beredarnya video prank si youtuber tersebut aksi prank juga dilakukan oleh empat orang remaja di Kabupaten Bone Sulawesi Selatan yang mendatangi rumah sakit dan mengaku sebagai pasien corona, aksi prank terhadap petugas rumah sakit ini sangatlah tidak terpuji terlebih lagi beban dan tekanan kerja petugas kesehatan saat ini sangat tinggi di tengah wabah corona. Perilaku-perilaku tidak terpuji yang dilakukan oleh remaja tersebut karena krisis moral yang berujung pada pelanggaran hukum. Sebegitu bobroknyakah etika anak muda di era milenial yang sepertinya tidak memiliki hati nurani di tengah musibah yang menimpa negeri ini untuk melakukan hal seperti itu demi eksistensi semata [6].

Fenomena perilaku amoral anak bangsa sangat mencemaskan dan meresahkan, bahkan telah mengganggu ketertiban umum dan membuat kehidupan tidak aman serta nyaman. Kalau hal ini tidak segera ditangani secara serius dan terencana yaitu dengan pendidikan nilai moral/agama, kemungkinan besar bangsa ini akan kehilangan generasi penerus. Kondisi ideal remaja sebagai generasi penerus, merupakan individu yang sedang berkembang, dan oleh karena itu perlu diberi kesempatan berkembang secara proporsional dan terarah, dan mendapatkan layanan pendidikan yang berimbang antara pengetahuan umum dan pendidikan nilai moral/agama. Mereka memiliki peran dan posisi strategis dalam kelangsungan kehidupan berbangsa dan bernegara [7].

Pendidikan moral mencakup pada pendekatan dan metode yang mengajarkan pada anak bangsa tentang pengetahuan, bersikap, keteramilan, keyakinan, dan tingkah laku moral yang baik, adil, benar, jujur, peduli terhadap sesama dan lain-lain [2]. Pastinya banyak orang tua yang menginginkan anaknya memiliki sikap dan perilaku yang baik serta mampu untuk memahami dan menyadari pentingnya suatu moral. Pendidikan moral itu perlu untuk dipahami dan dikenal oleh setiap orang. Huky [8] mengatakan bahwa dalam memahami moral dapat dilakukan dengan tiga cara: 
- Moral sebagai tingkah laku hidup manusia, yang mendasarkan diri pada kesadaraan, bahwa ia terikat oleh keharusan untuk mencapai yang baik sesuai dengan nilai dan norma yang berlaku dalam lingkungannya;

- Moral sebagai perangkat ide-ide tentang tingkah laku hidup, dengan warna dasar tertentu yang dipegang oleh sekelompok manusia di dalam lingkungan tertentu;

- Moral adalah ajaran tentang tinkah laku hidup yang baik berdasarkan pandangan hidup atau agama tertentu.

Pandangan Wilson tentang esensi dari pendidikan moral adalah menanamkan pilihan-pilihan yang benar dan klarifikasi akan perasaan dan disposisi tersebut. Pendidikan moral umumnya lebih menunjuk kepada pengembangan konsepsi keadilan yang begitu dipengaruhi oleh pemikiran-pemikiran Kant [9] moralitas mencakup makna yang begitu luas, antara lain:

- Tingkah laku membantu orang lain;

- Tingkah laku yang sesuai dengan norma-norma sosial;

- Internaliasasi norma-norma sosial;

- Timbulnya empati atau rasa salah, atau bahkan keduanya;

- Penalaran tentang keadilan, dan Memperhatikan kepentingan orang lain.

Pada dasarnya pelaksanaan pendidikan moral telah lama ada, tetapi hal tersebut semaikin lama semakin menipis dikarenakan kurangnya pemahaman dan kurang diaplikasikan dikehidupan sehari-hari. Serta dengan kemajuan zaman dan tingkah laku manusia pun berubah.

\section{B. Tujuan Pendidikan Moral}

Keberadaan moral sebagai landasan pendidikan sangat penting, karena sering terjadi masalah-masalah penyimpangan moral dalam dunia pendidikan [10]. Agar tidak terjadinya masalah-masalah tersebut, ada beberapa uraian mengenai tujuan pada Pendidikan moral. Tujuan pendidikan moral adalah membimbing para generasi muda untuk memahami dan menghayati Pancasila secara keseluruhan dan setiap sila. Tujuan akhirnya adalah agar dapat menumbuhkan manusia-manusia pembangunan yang dapat membangun dirinya sendiri serta bersama-sama bertanggungjawab atas pembangunan. Selain itu, tujuan Pendidikan moral adalah meningkatkan ketakwaan kepada Tuhan Yang Maha Esa, meningkatkan kecerdasan dan keterampilan, mempertinggi budi pekerti, memperkuat keperibadian, dan mempertebal semangat kebangsaan [1]. Dapat dikehatui bahwa Pendidikan moral bagi anak bangsa perlu adanya sebuah arahan atau bimbingan dalam memahami sebuah nilai Pancasila. Tujuan yang paling penting dari Pendidikan moral adalah agar anak bangsa mampu meningkatkan kapasitas pola berpikir secara moral, dapat membantu anak bangsa untuk mengenal apa yang menjadi dasar untuk menerima suatu nilai serta mampu mengarahkan anak bangsa dalam perkembangan yang optimal. Selain itu, dalam [1] bahwa pendidikan moral juga memiliki tujuan dan sasaran, antara lain:

- Perkembangan anak seutuhnya;

- Membina warga negara yang bertanggung jawab;

- Mengembangkan rasa hormat menghormati martabat individu dan kesucian hak asasi manusia;

- Menanamkan patriotisme dan integrasi nasional; Mengembangkan cara hidup dan berpikir demokratis;

- Mengembangkan toleransi, mengerti perbedaan;

- Mengembangkan persaudaraan;

- Mendorong tumbuhnya iman;

- Menanamkan prinsip moral.

\section{Implementasi Nilai-nilai Pancasila Bagi Anak Bangsa}

Sebagai dasar negara bangsa Indonesia, Pancasila terbukti sebagai salah satu media pemersatu dalam kehidupan berbangsa dan bernegara di Indonesia. Melalui kelima sila yang terkandung didalam Pancasila, menjadikan pondasi kehidupan bernegara di Indonesia menjadi kokoh terhadap ancaman yang datang baik dari luar maupun dari dalam. Sebagian nilai-nilai yang terkandung didalam Pancasila, dapat dirasakan dan dilihat ada sebagian masyarakat yang mengabaikan nilai-nilai Pancasila tersebut sehingga menimbulkan msalah-masalah yang serius, seperti korupsi, dekadensi moral, disintegrasi bangsa, kesadaran pajak, dan lain sebagainya. Pancasila sebagai dasar falsapah bangsa Indonesia harus tetap dijaga dan dirawat, agar Pancasila memiliki kesatuan yang utuh sebagai nilai, dan haluan bersama sebagai titik temu, titik tumpu, dan titik tuju.

Anak bangsa sebagai penerus bangsa atau sebagai generasi dalam memajukan bangsa Indonesia, harus memahai, melaksanakan, dan memiliki sikap dan perilaku sesuai pada nilai-nilai Pancasila. Anak bangsa harus menanamkan jiwa kemanusiaan, karena hal merupakan salah satu nilai Pancasila yang sudah mulai sulit ditemukan, seperti keadilan, kejujuran, keadaban, sikap toleransi, kebersamaan, peduli terhadap sesama, dan sebagainya. 
Sebagai suatu ideologi bangsa dan Negara Indonesia maka Pancasila pada hakikatnya bukan hanya merupakan suatu hasil perenungan atau pemikiran seseorang atau kelompok orang sebagaimana idelogi-ideologi lain di dunia, namun Pancasila diangkat dari nilai-nilai adat-istiadat, nilai-nilai kebudayaan serta nilai religius yang terdapat dalam pandangan hidup masyarakat Indonesia sebelum membentuk Negara, dengan lain perkatan unsurunsur yang merupakan materi (bahan) Pancasila tidak lain diangkat dari pandangan hidup masyarakat Indonesia sendiri, sehingga bangsa ini merupakan kausa materialis (asal bahan) Pancasila [5]. Dengan demikian, Pancasila sebagai ideologi bangsa Indonesia adalah sebagai keseluruhan pandangan, cita-cita, keyakinan, dan nilai-nilai bangsa Indonesia yang harus diimplementasikan dalam kehidupan, bermasyarakat, berbangsa dan bernegara [5].

\section{KESIMPULAN}

Nilai-nilai yang terdapat dalam masyarakat harus dibarengi dengan sebuah proses Pendidikan, karena Pendidikan sebagai salah satu sarana untuk tercapainya sebuah hasil atau harapan-harapan yang diinginkan. Hasil yang diperoleh dari pendidikan tidak hanya sebuah wawasan, ilmu, dan pengetahuan yang luas, tetapi dapat juga memperoleh akhlak yang baik, memiliki pengalaman yang berguna dan bermanfaat bagi masyarakat dan sebagainya. Memperoleh ilmu yang dapat diamalkan kepada banyak orang tentunya hal yang sangat positif dan memiliki nilai yang baik. Tetapi ilmu yang diamalkan kepada banyak orang tentunya harus dibarengi dengan sebuah adab, karena adab atau akhlak memiliki tingkatan tinggi dibandingkan dengan ilmu.Karena sebanyak apapun ilmu tanpa disertai dengan adab yang baik akan bisa menjadikan manusia pun berprilaku yang tidak sesuai nilai moral. Seperti kekerasan di sekolah maupun di luar sekolah, pembunuhan, pencurian, tawuran, dan sebagainya.Pendidikan moral bagi anak bangsa perlu adanya sebuah arahan atau bimbingan dalam memahami sebuah nilai Pancasila. Karena nilai Pancasila salah satu hal yang sangat penting yang perlu dikembangkan dan perlu untuk selalu mendapat perhatian. Agar nilai-nilai tersebut tidak diabaikan oleh anak bangsa maupun masyarakat Indonesia. Apabila nilai Pancasila luntur, maka identitas atau jati diri bangsa pun luntur.

Jadi, dapat disimpulkan banhwa implementasi nilai Pancasila sebagai Pendidikan moral bagi anak bangsa sangat diperlukan dan penting, karean seiring berjalannya perkembangan teknologi dan zaman, nilai-nilai tersebut harus dikembangkan dan ditanamkan pada anak bangsa untuk meningkatkan kesadaran anak pentingnya hal tersebut bagi kesejahteraan hidup. Jika, nilai-nilai Pancasila tidak dikenalkan atau tidak diajarkan, maka hal terebut akan memicu kelunturan identitas atau jati diri bangsa.

\section{SARAN}

Kita anak bangsa sebagai generasi penerus bangsa atau memajukan bangsa Indonesia ini, harus menjunjung tinggi nilai Pancasila. Seperti meningkatkan dalam bersikap dan berprilaku, meningkatkan ketakwaan dan keimanan kepada Tuhan Ynag Maha Esa, sikap saling mengahargai sebuah perbedaan, menjunjung tinggi keadilan, jujur, benar, mandiri, dan sebagainya. Penerapan nilai-nilai tersebut sebagai upaya pencerdasan moral serta meningkatkan kesadaran bagi anak bangsa, agar tidak terjadinya atau dapat mengurangi kasus penyimpangan moral. Dan harus kita ingat bahwa Pancasila merupakan landasan ideologi bangsa Indonesia, sebagai keseluruhan pandangan, cita-cita, keyakinan, dan nilai-nilai bangsa Indonesia yang harus diimplementasikan dalam kehidupan, bermasyarakat, berbangsa dan bernegara.

\section{DAFTAR PUSTAKA}

[1] Syaparuddin, S. PERANAN PENDIDIKAN NONFORMAL DAN SARANA PENDIDIKAN MORAL. JURNAL EDUKASI NONFORMAL, 1(1), 173-186, 2019.

[2] Ibda, F.. PENDIDIKAN MORAL ANAK MELALUI PENGAJARAN BIDANG STUDI PPKn DAN PENDIDIKAN AGAMA. Jurnal Ilmiah DIDAKTIKA, XII (2), pp. 338-347, 2012.

[3] Gumilang, G. S., n.d., METODE PENELITIAN KUALITATIF DALAM BIDANG BIMBINGAN DAN KONSELING. Jurnal Fokus Konseling, 2(2), 144-159, 2016.

[4] Damanhuri Damanhuri, F. A. B. W. H. L. I. N. R., IMPLEMENTASI NILAI-NILAI PANCASILA SEBAGAI UPAYA PEMBANGUNAN KARAKTER BANGSA. Untirta Civic Education Journal (UCEJ), 1(2), p. 186, 2016

[5] Asmaroini, A. P., Implementasi Nilai-Nilai Pancasila Bagi Siswa Di Era Globalisasi. Jurnal Pancasila dan Kewarganegaraan, 4(2), 2016

[6] Salimah, Krisis Moral yang Dialami Anak Muda di Era Milenial. PUSPENSOS,2020

[7] Ahmad Nawawi, 2011. Pentingnya Pendidikan moral bagi generasi muda. Jurnal Insania, 16(2), 131, 2011.

[8] Daroeso, Bambang. Dasar dan Konsep Pendidikan Moral Pancasila. Semarang: Aneka Ilmu, 1986

[9] Haricahyono, Cheppy. Dimensi-dimensi Pendidikan Moral. Semarang: Ikip Semarang Press, 1995.

[10] Ida Bagus Gede Bhaskara Manuaba, Y. K. H.,SOSIALISASI MORAL PADA ANAK-ANAK MELALUI MAPLALIAN. Jurnal Psikologi Udayana, 4(1), 2017. 